\title{
Pengaruh Kualitas Layanan Akademik terhadap Kepuasan dan Prestasi Peserta Didik
}

\author{
Novita Rahayu*, Mustiningsih, Raden Bambang Sumarsono \\ Universitas Negeri Malang, Jl. Semarang No. 5 Malang, Jawa Timur, Indonesia \\ *Penulis korespondensi, Surel: novitarahayu291195@gmail.com
}

Paper received: 28-9-2021; revised: 12-10-2021; accepted: 19-10-2021

\begin{abstract}
This study aims to determine (1) the level of academic service quality, (2) the level of student satisfaction, (3) the level of student achievement, (4) the influence of the quality of academic service on student satisfaction. (6) the influence of satisfaction on the achievement of learners, and (7) the influence of the quality of academic services on the achievement of learners mediated by the satisfaction of learners. The research method used, namely quantitative approach with descriptivecorrelational. Population in this research was as many as 1582. For sampling by using purposive sampling technique and stratified random sampling so that obtained by sampel as much as 323 respondents. In this study the questionnaire is used to collect data. The data analysis by using path analysis. The result of the research shows that: (1) the quality of the academic service quality is in the high category, (2) the students' satisfaction level in the high category, (3) the achievement level of the students is in the medium category, (4) 6) there is a significant influence of students' satisfaction on student achievement, and (7) there is significant influence of academic service quality toward the achievement of students who mediated with student satisfaction variable at SMPN in Ponggok sub-district, Blitar regency.
\end{abstract}

Keywords: academic service quality; satisfaction; achievement

\begin{abstract}
Abstrak
Penelitian ini bertujuan untuk mengetahui (1) tingkat kualitas layanan akademik, (2) tingkat kepuasan peserta didik, (3) tingkat prestasi peserta didik, (4) pengaruh kualitas layanan akademik terhadap kepuasan peserta didik, (5) pengaruh kualitas layanan akademik terhadap prestasi peserta didik, (6) pengaruh kepuasan terhadap prestasi peserta didik, dan (7) pengaruh kualitas layanan akademik terhadap prestasi peserta didik yang dimediasi oleh kepuasan peserta didik. Metode penelitian yang digunakan, yaitu pendekatan kuantitatif dengan deskriptif-korelasional. Populasi dalam penelitian ini sebanyak 1582. Untuk pengambilan sampel dengan menggunakan teknik purposive sampling dan stratified random sampling sehingga diperoleh sampel sejumlah 323 responden. Dalam penelitian ini angket digunakan untuk mengumpulkan data. Adapun untuk analisis data dengan menggunakan path analysis. Hasil penelitian menunjukkan bahwa: (1) tingkat kualitas kualitas layanan akademik berada pada kategori tinggi, (2) tingkat kepuasan peserta didik pada kategori tinggi, (3) tingkat prestasi peserta didik berada pada kategori sedang, (4) terdapat pengaruh yang signifikan kualitas layanan akademik terhadap kepuasan peserta didik (5) terdapat pengaruh yang signifikan kualitas layanan akademik terhadap prestasi peserta didik, (6) terdapat pengaruh yang signifikan kepuasan peserta didik terhadap prestasi peserta didik, dan (7) terdapat pengaruh yang signifikan kualitas layanan akademik terhadap prestasi peserta didik yang dimediasi oleh variabel kepuasan peserta didik pada SMPN se-Kecamatan Ponggok Kabupaten Blitar.
\end{abstract}

Kata kunci: kualitas layanan akademik; kepuasan; prestasi

\section{Pendahuluan}

Lembaga pendidikan merupakan suatu institusi yang menyelenggarakan dan menyediakan jasa pendidikan. Lembaga pendidikan merupakan organisasi sosial yang penting dalam mewariskan dan memelihara budaya di sekitarnya. Sekolah merupakan satuan 
pendidikan yang memberikan layanan kepada peserta didik, pada jalur formal, non formal, dan informal pada setiap jenjang pendidikan. Pendidikan nasional dijelaskan dalam UndangUndang Sistem Pendidikan Nasional Nomor 20 Tahun 2003 Pasal 3 yang menyebutkan:

Pendidikan nasional berfungsi mengembangkan kemampuan dan membentuk watak serta peradaban bangsa, bertujuan untuk berkembangnya potensi peserta didik agar menjadi manusia yang beriman dan bertaqwa kepada Tuhan Yang Maha Esa, berakhlak mulia, sehat, berilmu, cakap, kreatif, mandiri, dan menjadi warga negara yang demokratis serta bertanggung jawab.

Secara umum penyelenggaraan pendidikan di Indonesia memiliki tujuan untuk meningkatkan segala potensi yang dimiliki oleh peserta didik sehingga mencetak generasi muda yang berkualitas dan berkompeten. Perkembangan global yang begitu pesat diera modern seperti ini dapat menciptakan berbagai macam tantangan khususnya pada lingkup pendidikan. Masyarakat sebagai salah satu pengguna jasa pendidikan semakin kritis dan berharap penuh terhadap kinerja dari instansi pendidikan dalam membentuk outcome pendidikan yang bermutu dan berkualitas. Menurut Susanto (2016), dari segi kualitas, dunia pendidikan di Indonesia belum mampu memenuhi kebutuhan dan tantangan lingkup nasional dan global. Rendahnya mutu kualitas pendidikan yang ada di Indonesia dapat dilihat dari tingkat rendahnya pemerataan pendidikan bagi masyarakat, masih rendahnya mutu pendidikan dan relevansi pendidikan, serta masih lemahnya manajemen pendidikan. Rendahnya mutu pendidikan tentu akan memiliki implikasi terhadap prestasi peserta didik.

Produktivitas pada lembaga pendidikan berkaitan dengan proses dan penggunaan sumber daya yang ada secara komprehensif untuk mencapai tujuan pendidikan. Produktivitas sekolah merupakan perbandingan antara input dan output lembaga pendidikan. Output pendidikan merupakan suatu hasil yang diperoleh dari upaya sekolah dalam membentuk peserta didik yang berkualitas dan memiliki kompetensi. Menurut Susanto (2016), dimensi dan indikator sekolah yang produktif adalah lembaga yang mampu memberikan pengajaran bermutu, sehingga menciptakan prestasi belajar peserta didik. Prestasi peserta didik merupakan indikator keberhasilan proses pembelajaran dan penyelenggaraan pendidikan.

Prestasi akademik adalah cerminan prestasi yang dicapai oleh peserta didik dan berkaitan dengan keberhasilan tentang tujuan yang disebabkan oleh suatu usaha belajar yang dilakukan secara optimal (Anggara, 2015). Sedangkan pengertian prestasi non akademik merupakan prestasi yang dicapai peserta didik dan berkaitan dengan potensi bakat dan minat peserta didik yang dikembangkan secara optimal. Prestasi non akademik merupakan bentuk kegiatan yang menunjang program akademik di sekolah, agar tercapai tujuan pendidikan yang lebih komprehensif (Anggara, 2015). Dari pernyataan tersebut dapat dimaknai bahwa, prestasi peserta didik merupakan capaian yang terkait dengan kemampuan peserta didik dalam menangkap isi dan pesan kegiatan belajar di sekolah.

Kualitas pelayanan yang baik adalah pelayanan yang menjamin kepuasan bagi pengguna jasa pendidikan (Mustain, 2017). Kualitas pelayanan terutama pada bidang jasa, memfokuskan pada upaya untuk memenuhi keinginan dan kebutuhan pengguna jasa, serta kesesuaian pemenuhannya untuk menyesuaikan harapan yang diinginkan oleh pengguna jasa. Menurut Tjiptono (2007), kualitas pelayanan (service quality) akademik dapat diketahui dengan membandingkan persepsi yang dimiliki oleh peserta didik atas layanan akademik yang diterima, dengan layanan akademik yang diharapkan. Apabila jasa yang diterima (perceived 
service) peserta didik sesuai dengan harapannya, maka kualitas pelayanan berada dalam kategori baik dan memuaskan. Namun, apabila jasa yang diperoleh peserta didik tidak sesuai dengan harapannya, maka dapat dikatakan tidak memuaskan. Kualitas layanan akademik sangat penting dan harus dikelola dengan maksimal agar dapat meningkatkan layanan yang memuaskan. Hal ini sesuai dengan penelitian Sumarsono (2012), yang menyatakan bahwa salah satu faktor yang paling menonjol dan mendominasi pengaruh terhadap kepuasan pengguna jasa adalah kualitas layanan yang diberikan. Layanan akademik yang berkualitas dapat meningkatkan prestasi peserta didik. Pengalaman yang diperoleh dari pemberian layanan akademik yang berwujud prestasi merupakan bentuk image sekolah.

Dalam kaitannya untuk menciptakan kepuasan peserta didik, jasa yang diberikan lembaga pendidikan harus memiliki kualitas yang baik. Secara singkat kualitas memiliki pengertian sebagai produk yang sempurna dan bebas cacat. Kualitas kemudian diperluas menjadi fitnes for use dan conformance to requirement yang memiliki makna bahwa, jasa harus memiliki manfaat dalam penggunaannya dan memiliki kesesuaian dengan kebutuhan pengguna. Kualitas menggambarkan tawaran terhadap produk yang dapat menghasilkan manfaat (benefit) bagi pelanggan. Dalam hubungannya dengan kepuasan pengguna jasa, kualitas memiliki beberapa dimensi pokok. Berikut ini adalah beberapa acuan dimensi pokok penentu kualitas layanan jasa menurut Parasuraman et. al dalam Tjiptono dan Chandra (2012) yaitu terdiri dari, (1) reliability, (2) responsiveness, (3) assurance, (4) empathy, dan (5) tangible. Dari lima dimensi pokok tersebut, merupakan faktor penentu utama kualitas pelayanan akademik yang harus diterapkan oleh lembaga pendidikan, karena dari kelima dimensi inilah yang dapat meningkatkan kesuksesan dan visi lembaga, serta dapat memberikan kepuasan terhadap pengguna jasa pendidikan. Kualitas layanan akan mempengaruhi pelanggan (peserta didik) dalam menggunakan suatu jasa yang diberikan, sehingga kualitas layanan sangat penting untuk dikelola dengan baik.

Sekolah memiliki peran penting dalam memberikan layanan yang bermutu kepada peserta didik. Sesuai dengan pendapat Cash, dkk yang termuat dalam Prastiawan, dkk (2016: 215) menyatakan, "A good school facility supports the educational enterprise". Hal ini dapat diartikan bahwa, sekolah yang baik adalah sekolah yang menyediakan fasilitas untuk mendukung pelayanan pendidikan. Mutu pendidikan menurut Susanto (2016) yaitu, mengacu pada hasil pendidikan yang dicapai oleh sekolah dalam bentuk prestasi peserta didik. Prestasi yang dicapai oleh peserta didik atau (student achievement) dapat dilihat dari hasil tes kemampuan akademik. Perbedaan penelitian ini dengan penelitian yang lain adalah terletak pada variabel prestasi peserta didik yang dipengaruhi oleh kualitas layanan akademik yang diberikan sekolah. Perbedaan lainnya terletak pada lokasi penelitian, dimana penelitian Sumarsono dilakukan pada mahasiswa di Fakultas Ilmu Pendidikan Universitas Negeri Malang, dan penelitian Sari dan Wiyono dilakukan di Sekolah Menengah Kejuruan Negeri (SMKN) Kota Malang, sementara itu pada penelitian ini dilakukan di SMPN Kecamatan Ponggok Kabupaten Blitar. Dan perbedaan berikutnya terletak pada penggunaan teknik analisis data yang digunakan oleh peneliti sebelumnya. Penelitian ini penting dilakukan untuk mengetahui tingkat kualitas pelayanan akademik yang diberikan oleh lembaga pendidikan, maka dapat diketahui kontribusi dan pengaruhnya terhadap kepuasan dan prestasi peserta didik. 


\section{Metode}

Penelitian ini melakukan pengolahan data dengan metode pendekatan kuantitatif deskriptif korelasional, dengan menggunakan teknik analisis data path analysis. Teknik ini digunakan agar dapat menggambarkan pengaruh antara variabel eksogen yaitu X (Kualitas Layanan Akademik), dan variabel endogen $Y_{1}$ (Kepuasan) dan $Y_{2}$ (Prestasi Peserta Didik). Berdasarkan rancangan penelitian tersebut dapat diartikan bahwa pengaruh $\mathrm{X}$ terhadap $\mathrm{Y}_{1}$, pengaruh $X$ terhadap $Y_{2}$, dan disebut pengaruh langsung jika dari $Y_{1}$ ke $Y_{2}$, sedangkan disebut pengaruh tidak langsung jika $X$ terhadap $Y_{2}$ melalui $Y_{1}$. Lokasi penelitian ini adalah SMP Negeri Se-Kecamatan Ponggok Kabupaten Blitar. Populasi dalam penelitian ini berjumlah 1582 peserta didik, dan menentukan sampel penelitian dengan teknik stratified random sampling untuk menentukan jumlah sampel secara acak dan berlapis, dan teknik purposive sampling digunakan untuk menentukan jumlah sampel pada tiap kelas. Pengambilan sampel dilakukan dengan menggunakan rumus Slovin (Darmawan, 2014) dan diperoleh jumlah sampel sebesar 323 peserta didik.

Pengambilan data dilakukan dengan menggunakan teknik kuesioner yang berisi beberapa pernyataan untuk menggali informasi mengenai pengaruh kualitas layanan akademik terhadap prestasi peserta didik. Angket tersebut dilakukan uji coba terhadap 60 responden di luar sampel penelitian. Pernyataan variabel X berjumlah 42 dan berdasarkan hasil uji validitas pada variabel kualitas layanan akademik (X), terdapat 42 item pernyataan, yang secara keseluruhan item pernyataan tersebut dapat dikatakan valid dengan koefisien korelasi $\mathrm{r}_{\text {hitung }}$ lebih dari 0,2542 . Uji validitas pada variabel kepuasan peserta didik $\left(\mathrm{Y}_{1}\right)$ yang terdiri dari 20 item pernyataan, ada 2 item yang tidak valid dan 18 item yang dinyatakan valid, 18 item pernyataan dikatakan valid dikarenakan koefisien korelasi $\left(\mathrm{r}_{\text {hitung }}\right)$ lebih dari 0,2542.

Teknik analisis data dengan menggunakan teknik path analysis. Teknik ini digunakan untuk menggambarkan pengaruh antara variabel eksogen yaitu $X$ (Kualitas Layanan Akademik), dan variabel endogen $Y_{1}$ (Kepuasan) dan $Y_{2}$ (Prestasi Peserta Didik).

\section{Hasil dan Pembahasan}

\subsection{Hasil}

Deskripsi hasil penelitian diolah dengan menentukan nilai Method of Succesive Interval (MSI) terlebih dahulu, kemudian dilakukan pengolahan uji hipotesis dengan menggunakan Statistic Product and Service Solution (SPSS) 21 for Windows. Deskripsi hasil penelitian dipaparkan pada Tabel 1 .

Tabel 1. Ringkasan Analisis Deskriptif Variabel Koefisien Penelitian

\begin{tabular}{lllllllll}
\hline $\begin{array}{l}\text { Variabel } \\
\text { Koefisien }\end{array}$ & Reliability & Responsiveness & Assurances & Empathy & Tangibel & $\begin{array}{l}\text { Kualitas } \\
\text { Layanan } \\
\text { Akademik }\end{array}$ & Kepuasan & $\begin{array}{l}\text { Prestasi } \\
\text { Peserta } \\
\text { Didik }\end{array}$ \\
\hline Rata-rata & 13.79801 & 18.32993 & 53.3055 & 14.82172 & 46.66979 & 146.925 & 62.67687 & 50 \\
Deviasi & 2.568623 & 2.781505 & 6.967018 & 2.972223 & 7.277382 & 17.90039 & 9.271918 & 10 \\
Standar & & & & & & & & \\
Varian & 6.598 & 7.737 & 48.539 & 8.834 & 52.96 & 320.424 & 85.968 & 100 \\
Kurtosis & -0.366 & -0.178 & -0.072 & -0.078 & -0.599 & 0,124 & 0.236 & -0.098
\end{tabular}




\begin{tabular}{|c|c|c|c|c|c|c|c|c|}
\hline $\begin{array}{l}\text { Variabel } \\
\text { Koefisien }\end{array}$ & Reliability & Responsiveness & Assurances & Empathy & Tangibel & $\begin{array}{l}\text { Kualitas } \\
\text { Layanan } \\
\text { Akademik }\end{array}$ & Kepuasan & $\begin{array}{l}\text { Prestasi } \\
\text { Peserta } \\
\text { Didik }\end{array}$ \\
\hline (Distribusi) & Normal & Normal & Normal & Normal & Normal & Normal & Normal & Normal \\
\hline \multirow{2}{*}{$\begin{array}{l}\text { Skewness } \\
\text { (Distribusi) }\end{array}$} & -0.082 & -0.45 & \multirow{2}{*}{$\begin{array}{l}-0.218 \\
\text { Normal }\end{array}$} & \multirow{2}{*}{$\begin{array}{l}-0.197 \\
\text { Normal }\end{array}$} & \multirow{2}{*}{$\begin{array}{l}-0.256 \\
\text { Normal }\end{array}$} & -.236 & -0.028 & -0.261 \\
\hline & Normal & Normal & & & & Normal & Normal & Normal \\
\hline $\begin{array}{l}\text { Skor } \\
\text { Minimum }\end{array}$ & 5.6941 & 10.0735 & 30.6367 & 5.9739 & 27.887 & 87.8686 & 32.1406 & 20.1455 \\
\hline $\begin{array}{l}\text { Skor } \\
\text { Maksimum }\end{array}$ & 18.4186 & 23.2603 & 69.3179 & 21.5757 & 60.3312 & 185.275 & 85.2879 & 71.6591 \\
\hline Rentangan & 12.7245 & 13.1868 & 38.6812 & 15.6018 & 32.444 & 97.4064 & 53.1473 & 51.5136 \\
\hline Jumlah Skor & 4456.758 & 5920.567 & 17217.68 & 4787.416 & 15074.34 & 47456.76 & 20244.63 & 16150 \\
\hline N (Sampel) & 323 & 323 & 323 & 323 & 323 & 323 & 323 & 323 \\
\hline $\begin{array}{l}\text { Peluang } \\
\text { Maks }\end{array}$ & 18.419 & 23.26 & 69.318 & 21.576 & 60.331 & 185.275 & 85.288 & 71.659 \\
\hline $\begin{array}{l}\text { Peluang } \\
\text { Minim }\end{array}$ & 4 & 5 & 15 & 5 & 13 & 42 & 18 & 20.145 \\
\hline $\begin{array}{l}\text { Rentangan } \\
\text { Peluang }\end{array}$ & 14.419 & 18.26 & 54.318 & 16.576 & 47.331 & 143.275 & 67.288 & 51.514 \\
\hline Interval & 4.806 & 6.087 & 18.10596 & 5.525222 & 15.77707 & 50.30122 & 22.429 & 17.1712 \\
\hline $\begin{array}{l}\text { Kategori } \\
\text { Rendah }\end{array}$ & $\leq 8.805$ & $\leq 11.086$ & $\leq 33.105$ & $\leq 10.524$ & $\leq 28.776$ & $\leq 92,300$ & $\leq 40.428$ & $\leq 37.316$ \\
\hline $\begin{array}{l}\text { Kategori } \\
\text { Sedang }\end{array}$ & $\leq 13.611$ & $\leq 17.173$ & $\leq 51.211$ & $\leq 16.049$ & $\leq 44.553$ & $\leq 142,601$ & $\leq 62.858$ & $\leq 54.487$ \\
\hline $\begin{array}{l}\text { Kategori } \\
\text { Tinggi }\end{array}$ & $\geq 13.612$ & $\geq 17.174$ & $\geq 51.212$ & $\geq 16.050$ & $\geq 44.554$ & $\geq 142,602$ & $\geq 62.859$ & $\geq 54.488$ \\
\hline
\end{tabular}

Berdasarkan Tabel 1, dapat dijelaskan gambaran atau deskripsi tentang kepuasan peserta didik, kualitas layanan akademik, dan prestasi peserta didik. Berikut ini akan diuraikan deskripsi secara detail terkait masing-masing variabel penelitian ini.

\subsubsection{Kepuasan Peserta Didik}

Kepuasan diukur dengan menggunakan indikator : (1) Kesesuaian harapan atas jasa yang diberikan oleh sekolah, (2) Kesesuaian harapan atas fasilitas di sekolah, (3) Memberikan anjuran kepada anggota keluarga, (4) Memberikan anjuran kepada teman, (5) Memiliki rasa kasih sayang terhadap layanan di sekolah, dan (6) Memiliki hak atas layanan di sekolah. Deskripsi data variabel kepuasan dari 323 responden secara keseluruhan panjang interval dalam variabel kepuasan dalam penelitian ini adalah 22.429. Berdasarkan diagram di atas menunjukkan bahwa secara keseluruhan menyatakan 0,3\% dalam kategori rendah dengan jumlah responden yang memilih 1 orang, 8,7\% dalam kategori sedang dengan jumlah responden sebanyak 28 orang, dan 91,0 \% dalam kategori tinggi dengan jumlah responden sebesar 294 orang. Perhitungan deskripsi variabel prestasi peserta didik disajikan pada Tabel 2 . 
Tabel 2. Distribusi Frekuensi dan Persentase Variabel Kepuasan

\begin{tabular}{ccccccc}
\hline No & Interval & & & Kriteria & Frekuensi & Persentase \\
\hline 1 & 18,000 & - & 40,428 & Rendah & 1 & $0,3 \%$ \\
2 & 40,429 & - & 62,858 & Sedang & 28 & $8,7 \%$ \\
3 & 62,859 & - & 85.288 & Tinggi & 294 & $91,0 \%$ \\
\hline Total & & & & & 323 & $100 \%$ \\
\hline
\end{tabular}

\subsubsection{Prestasi Peserta Didik}

Prestasi peserta didik diukur dengan menggunakan indikator : (1) Nilai Rata-rata Semester, dan (2) Kejuaraan Perlombaan. Indikator-indikator pada angket penelitian tersebut diambil dari data masing-masing sekolah. Masing-masing indikator dihitung berdasarkan kelas interval dengan rentang nilai 1-3. Deskripsi data variabel prestasi peserta didik dari 323 responden secara keseluruhan panjang interval dalam variabel prestasi peserta didik dalam penelitian ini adalah 17.17120405. Berdasarkan diagram di atas menunjukkan bahwa secara keseluruhan menyatakan 5,0\% dalam kategori rendah dengan jumlah responden yang memilih 16 orang, 47,7\% dalam kategori sedang dengan jumlah responden sebanyak 154 orang, dan $47,4 \%$ dalam kategori tinggi dengan jumlah responden sebesar 153 orang. Perhitungan deskripsi variabel prestasi peserta didik dapat dilihat pada Tabel 3.

Tabel 3. Distribusi Frekuensi dan Persentase Variabel Prestasi Peserta Didik

\begin{tabular}{|c|c|c|c|c|c|}
\hline No & Interval & & Kriteria & Frekuensi & Persentase \\
\hline 1 & 20,145 & 37,316 & Rendah & 16 & $5,0 \%$ \\
\hline 2 & 37,317 & $\begin{array}{l}-\quad 54,487\end{array}$ & Sedang & 154 & $47,7 \%$ \\
\hline 3 & 54,488 & $\begin{array}{l}-\quad 71.659 \\
\end{array}$ & Tinggi & 153 & $47,3 \%$ \\
\hline \multicolumn{4}{|c|}{ Total } & 323 & $100 \%$ \\
\hline
\end{tabular}

\subsubsection{Kualitas Layanan Akademik}

Berdasarkan uraian hasil penelitian, maka dapat ditarik kesimpulan bahwa tingkat kualitas layanan akademik di SMPN se Kecamatan Ponggok berada pada kategori tinggi. Hal ini dapat dilihat dari jumlah persentase dalam kategori rendah sejumlah $0.6 \%$ dengan frekuensi 2 responden. Kategori sedang memiliki persentase sejumlah $37,8 \%$ dengan frekuensi berjumlah 122 responden. Jumlah frekuensi dalam kategori tinggi berjumlah 199 responden dengan persentase $61,6 \%$. Sehingga berdasarkan penjelasan di atas, maka ditarik kesimpulan bahwa tingkat kualitas layanan akademik di SMPN se Kecamatan Ponggok Kabupaten Blitar dalam kategori tinggi. Distribusi frekuensi untuk variabel kualitas layanan akademik dipaparkan pada Tabel 4 .

Tabel 4. Distribusi Frekuensi dan Persentase Variabel Kualitas Layanan Akademik

\begin{tabular}{ccccccc}
\hline No & Interval & & & Kriteria & Frekuensi & Persentase \\
\hline 1 & 42,000 & - & 93,300 & Rendah & 2 & $0,6 \%$ \\
2 & 93,301 & - & 142,601 & Sedang & 122 & $37,8 \%$ \\
3 & 142,602 & - & 192,903 & Tinggi & 199 & $61,6 \%$ \\
\hline Total & & & & 323 & $100 \%$ \\
\hline
\end{tabular}


Deskripsi data variabel reliability dari 323 responden secara keseluruhan panjang interval dalam variabel reliability dalam penelitian ini adalah 4,806. Berdasarkan hasil olah data menunjukkan bahwa secara keseluruhan menyatakan 3,1\% dalam kategori rendah dengan jumlah responden 10 orang, 48,9\% dalam kategori sedang dengan jumlah responden sebanyak 158 orang, dan $48 \%$ dalam kategori tinggi dengan jumlah responden sebesar 155 orang. Deskripsi data variabel responsiveness dari 323 responden secara keseluruhan panjang interval dalam variabel responsiveness dalam penelitian ini adalah 6.087. Berdasarkan hasil olah data menunjukkan bahwa secara keseluruhan menyatakan $0 \%$ dalam kategori rendah, 5,6\% dalam kategori sedang dengan jumlah responden sebanyak 18 orang, dan 94,4\% dalam kategori tinggi dengan jumlah responden sebesar 305 orang. Deskripsi data variabel assurances dari 323 responden secara keseluruhan panjang interval dalam variabel assurances dalam penelitian ini adalah 18.1059626. Berdasarkan hasil olah data menunjukkan bahwa secara keseluruhan menyatakan $0,6 \%$ dalam kategori rendah dengan jumlah responden yang memilih 2 orang, 35,3\% dalam kategori sedang dengan jumlah responden sebanyak 114 orang, dan 64,1\% dalam kategori tinggi dengan jumlah responden sebesar 207 orang.

Deskripsi data variabel empathy dari 323 responden secara keseluruhan panjang interval dalam variabel empathy dalam penelitian ini adalah 5.525221722. Berdasarkan diagram di atas menunjukkan bahwa secara keseluruhan menyatakan 8,4\% dalam kategori rendah dengan jumlah responden yang memilih 27 orang, 57,9\% dalam kategori sedang dengan jumlah responden sebanyak 187 orang, dan 33,7 \% dalam kategori tinggi dengan jumlah responden sebesar 109 orang. Deskripsi data variabel tangible dari 323 responden secara keseluruhan panjang interval dalam variabel tangible dalam penelitian ini adalah 15.77706969. Berdasarkan hasil olah data menunjukkan bahwa secara keseluruhan menyatakan 3,1\% dalam kategori rendah dengan jumlah responden yang memilih 10 orang, $66,3 \%$ dalam kategori sedang dengan jumlah responden sebanyak 214 orang, dan 30,7 \% dalam kategori tinggi dengan jumlah responden sebesar 99 orang.

\subsubsection{Pengaruh $\mathrm{X}$ terhadap $\mathrm{Y}_{1}$}

Struktur pertama dalam analisis jalur ini tampak pada Gambar 1.

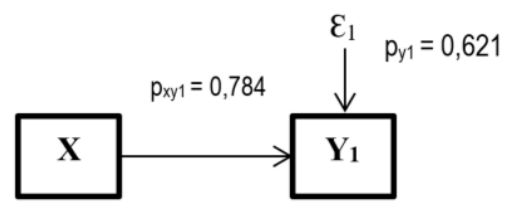

\section{Gambar 1. Model Spesifikasi Struktur Analisis Jalur Pertama}

Pengujian koefisien jalur pada struktur I diperoleh nilai koefisien jalur X terhadap $\mathrm{Y}_{1}$ sebesar $\mathrm{p}_{\mathrm{xy} 1}=$ Beta $=0,784$. Nilai $\mathrm{t}$ sebesar 22,168 dengan probabilitas signifikansi $=0,000$. Nilai signifikansi $0,000<0,05$, sehingga $\mathrm{H}_{0}$ ditolak. Sehingga, ditarik kesimpulan bahwa terdapat pengaruh yang signifikan kualitas layanan (service quality) akademik terhadap kepuasan peserta didik pada SMPN se-Kecamatan Ponggok Kabupaten Blitar. Sedangkan untuk nilai kontribusi kualitas layanan (service quality) akademik terhadap kepuasan peserta didik sebesar $0,614 \times 100 \%=61,4 \%$. 


\subsubsection{Pengaruh $X$ terhadap $Y_{2}$}

Struktur II dalam analisis jalur ini tampak pada Gambar 2.

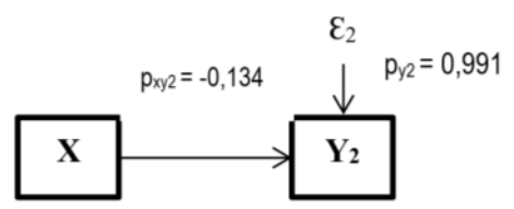

\section{Gambar 2. Model Spesifikasi Struktur Analisis Jalur Kedua}

Pengujian koefisien jalur pada struktur II diperoleh nilai koefisien jalur X terhadap $\mathrm{Y}_{2}$ sebesar $\mathrm{p}_{\mathrm{xy2} 2}=\mathrm{Beta}=-0,134$. Nilai $\mathrm{t}$ sebesar $-2,422$ dengan probabilitas signifikansi $=0,016$. Nilai signifikansi $0,016<0,05$, sehingga $\mathrm{H}_{0}$ ditolak. Sehingga, ditarik kesimpulan bahwa ada pengaruh yang signifikan kualitas layanan(service quality) akademik terhadap prestasi peserta didik pada SMPN se-Kecamatan Ponggok Kabupaten Blitar. Sedangkan untuk nilai kontribusi kualitas layanan (service quality) akademik terhadap prestasi peserta didik sebesar 0,018 x $100 \%=1,8 \%$.

\subsubsection{Pengaruh $Y_{1}$ terhadap $Y_{2}$}

Struktur III dalam analisis jalur ini tampak pada Gambar 3.

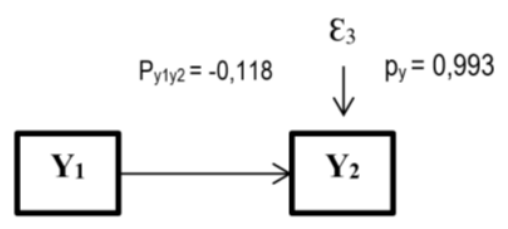

\section{Gambar 3. Model Spesifikasi Struktur Analisis Jalur Ketiga}

Pengujian koefisien jalur pada struktur III diperoleh nilai koefisien jalur $Y_{1}$ terhadap $Y_{2}$ sebesar $\mathrm{p}_{\mathrm{y} \mathrm{y}_{\mathrm{y}}}=$ Beta $=-0,118$. Nilai $\mathrm{t}$ sebesar $-2,121$ dengan probabilitas signifikansi $=0,035$. Nilai signifikansi $0,035<0,05$, sehingga $\mathrm{H}_{0}$ ditolak. Sehingga, ditarik kesimpulan bahwa ada pengaruh yang signifikan kepuasan peserta didik terhadap prestasi peserta didik pada SMPN se-Kecamatan Ponggok Kabupaten Blitar. Sedangkan untuk nilai kontribusi kepuasan peserta didik terhadap prestasi peserta didik sebesar $0,014 \times 100 \%=1,4 \%$.

\subsubsection{Pengaruh $X$ terhadap $Y_{2}$ melalui $Y_{1}$}

Langkah yang dilakukan untuk melihat pengaruh Kualitas Layanan(service quality) Akademik $(\mathrm{X})$ terhadap Prestasi $\left(\mathrm{Y}_{2}\right)$ yang dimediasi atau melalui variabel Kepuasan Peserta Didik $\left(\mathrm{Y}_{1}\right)$ dengan mengalikan masing-masing nilai beta. Nilai pengaruh hal tersebut sebesar $p_{\mathrm{xy} 1} \cdot p_{\mathrm{y} 1 \mathrm{y} 2}=(0,784) \cdot(-0,118)=-0,092$. Sedangkan nilai kontribusinya dapat dilakukan dengan perhitungan $(-0,092)^{2} \times 100 \%=0,8 \%$. 


\subsection{Pembahasan}

Kualitas layanan akademik secara umum adalah tingkat kualitas layanan akademik di SMPN se Kecamatan Ponggok dalam kategori tinggi. Hal tersebut bisa dilihat dari jumlah persentase dalam kategori rendah sejumlah 0,6\% dengan frekuensi 2 responden. Kategori sedang memiliki persentase sejumlah 37,8\% dengan frekuensi berjumlah 122 responden. Jumlah frekuensi dalam kategori tinggi berjumlah 199 responden dengan persentase 61,6\%. Sehingga berdasarkan penjelasan di atas, sehingga dapat disimpulkan bahwa tingkat kualitas layanan akademik di SMPN se-Kecamatan Ponggok Kabupaten Blitar dalam kategori tinggi.

Hal tersebut sesuai dengan pendapat Tjiptono (2007), bahwa kualitas pelayanan (service quality) akademik dapat dilihat dengan membandingkan persepsi yang dimiliki oleh peserta didik atas layanan akademik yang diterima, dengan layanan akademik yang diharapkan. Apabila harapan yang dimiliki dipenuhi dengan pelayanan atau jasa yang diberikan, maka kualitas pelayanan dipersepsikan dalam kategori baik dan memuaskan. Sedangkan menurut Mustain (2017), kualitas pelayanan yang baik adalah pelayanan yang menjamin kepuasan bagi pengguna jasa pendidikan. Kualitas pelayanan terutama pada bidang jasa, memfokuskan pada upaya untuk mencukupi kebutuhan dan keinginan pengguna jasa, serta ketepatan pemenuhannya untuk mengimbangi harapan yang diinginkan oleh pengguna jasa.

Kemudian hasil penelitian variabel kualitas layanan akademik dirinci ke dalam sub-sub variabelnya. Deskripsi data variabel reliability dari 323 responden secara keseluruhan panjang interval dalam variabel reliability dalam penelitian ini adalah 4,806. Hasil analisis deskriptif menunjukkan bahwa secara keseluruhan menyatakan 3,1\% dalam kategori rendah dengan jumlah responden 10 orang, 48,9\% dalam kategori sedang dengan jumlah responden sebanyak 158 orang, dan $48 \%$ dalam kategori tinggi dengan jumlah responden sebesar 155 orang. Hal ini berarti responden cenderung menyatakan sub variabel reliability dalam kategori sedang. Hasil pengolahan data tersebut sesuai dengan kajian teori tentang reliability yang menerangkan bahwa reliability (Keandalan), yaitu kemampuan untuk mewujudkan pelayanan akademik yang dijanjikan dengan handal dan akurat (Tjiptono \& Chandra, 2012).

Variabel responsiveness menunjukkan bahwa secara keseluruhan menyatakan $0 \%$ dalam kategori rendah, 5,6\% dalam kategori sedang dengan jumlah responden sebanyak 18 orang, dan $94,4 \%$ dalam kategori tinggi dengan jumlah responden sebesar 305 orang. Sehingga ini berarti bahwa responden cenderung menyatakan bahwa responsiveness tergolong dalam kategori tinggi. Hal ini sesuai dengan kajian teori tentang responsiveness (daya tanggap), yaitu keinginan atau kesanggupan untuk membantu peserta didik dengan memberikan pelayanan akademik yang cepat dan tepat (Tjiptono \& Chandra, 2012).

Variabel assurances menunjukkan bahwa bahwa secara keseluruhan menyatakan 0,6\% dalam kategori rendah dengan jumlah responden yang memilih 2 orang, 35,3\% dalam kategori sedang dengan jumlah responden sebanyak 114 orang, dan 64,1\% dalam kategori tinggi dengan jumlah responden sebesar 207 orang. Sehingga ini berarti responden cenderung menyatakan bahwa assurances tergolong dalam kategori tinggi. Hal ini sesuai dengan kajian teori tentang assurances yaitu merupakan kemampuan, pengetahuan, dan kesopanan atau kebaikan dari personal individu yang memberikan layanan akademik serta kemampuan untuk mendapatkan kepercayaan (Tjiptono \& Chandra, 2012). 
Variabel empathy menunjukkan bahwa secara keseluruhan menyatakan 8,4\% dalam kategori rendah dengan jumlah responden yang memilih 27 orang, 57,9\% dalam kategori sedang dengan jumlah responden sebanyak 187 orang, dan 33,7 \% dalam kategori tinggi dengan jumlah responden sebesar 109 orang. Sehingga ini berarti responden cenderung menyatakan bahwa empathys tergolong dalam kategori sedang. Paparan di atas sesuai dengan kajian teori tentang empathy yaitu penyedia layanan akademik yang memperhatikan secara individu atau pribadi atas keperluan peserta didik (Tjiptono \& Chandra, 2012).

Variabel tangible menunjukkan bahwa secara keseluruhan menyatakan 3,1\% dalam kategori rendah dengan jumlah responden yang memilih 10 orang, 66,3\% dalam kategori sedang dengan jumlah responden sebanyak 214 orang, dan 30,7 \% dalam kategori tinggi dengan jumlah responden sebesar 99 orang. Sehingga ini berarti responden cenderung menyatakan tangible tergolong dalam kategori sedang. Hal ini sesuai dengan kajian teori tentang tangible yaitu suatu bentuk fasilitas pendukung, peralatan atau perlengkapan, dan bentuk fisik penyelenggara layanan akademik.

Kelima dimensi kualitas tersebut merupakan karakteristik yang dijadikan acuan untuk mengukur kualitas produk atau jasa yang telah dijelaskan oleh Tjiptono dan Chandra (2012). Untuk menganalisis kualitas layanan akademik dengan baik dan benar maka menggunakan kelima dimensi yang telah disebutkan di atas. Tetapi jika tidak menggunakan kelima dimensi untuk menganalisis karakteristik layanan akademik, maka layanan tersebut tidak dapat diketahui kualitasnya dengan baik dan benar.

Deskripsi data variabel kepuasan dari 323 responden secara keseluruhan panjang interval dalam variabel kepuasan dalam penelitian ini adalah 22.429. Berdasarkan diagram di atas menunjukkan bahwa secara keseluruhan menyatakan 0,3\% dalam kategori rendah dengan jumlah responden yang memilih 1 orang, 8,7\% dalam kategori sedang dengan jumlah responden sebanyak 28 orang, dan 91,0 \% dalam kategori tinggi dengan jumlah responden sebesar 294 orang. Sehingga ditarik kesimpulan bahwa tingkat kepuasan peserta didik pada kategori tinggi. Hal ini sesuai dengan pendapat Mustain (2017), kualitas pelayanan yang baik adalah pelayanan yang menjamin kepuasan bagi pengguna jasa pendidikan. Kesesuaian harapan peserta didik terhadap layanan yang diberikan oleh sekolah berdampak pada kepuasan peserta didik, namun jika harapan yang dimiliki tidak terpenuhi secara maksimal maka tidak menciptakan rasa kepuasan.

Deskripsi data variabel prestasi peserta didik dari 323 responden secara keseluruhan panjang interval dalam variabel prestasi peserta didik dalam penelitian ini adalah 17.17120405. Berdasarkan hasil penelitian menunjukkan bahwa secara keseluruhan menyatakan 5,0\% dalam kategori rendah dengan jumlah responden yang memilih 16 orang, $47,7 \%$ dalam kategori sedang dengan jumlah responden sebanyak 154 orang, dan 47,4 \% dalam kategori tinggi dengan jumlah responden sebesar 153 orang. Sehingga dapat disimpulkan bahwa prestasi peserta didik SMPN se-Kecamatan Ponggok Kabupaten Blitar dalam kategori sedang.

Paparan di atas sesuai dengan pendapat Winkel dalam Anita (2016: 35), prestasi merupakan sebuah bukti dari keberhasilan suatu usaha yang telah dicapai, yang memiliki proses mental yang mengarah pada penguasaan, pengetahuan, kecakapan, kebiasaan, atau sikap yang diperoleh, disiplin, dan dilakukan sehingga menimbulkan tingkah laku. Prestasi peserta didik diperoleh melalui aktivitas belajar mengajar di sekolah. Menurut Dimyati dan 
Mudjiono (2009), proses belajar dapat terjadi atau bertambah maksimal apabila didorong dengan lingkungan peserta didik yang mumpuni dan berkualitas, baik dari segi fisik maupun nonfisik. Prestasi merupakan produk yang dihasilkan dari pemberian jasa berupa layanan akademik di sekolah. Hal tersebut sejalan dengan pendapat Susanto (2016), yang menyatakan produktivitas dalam lembaga pendidikan merupakan suatu proses penataan dan penggunaan sumber daya secara komprehensif untuk mencapai tujuan pendidikan secara efektif dan efisien. Tujuan pendidikan adalah meningkatkan dan mengembangkan kemampuan peserta didik. Prestasi peserta didik dapat tercapai apabila sekolah memberikan produk berupa jasa secara komprehensif dan maksimal. Keseluruhan proses yang dimaksud berupa layanan akademik untuk peserta didik yang berkualitas. Pemberian layanan akademik yang berkualita dapat berkontribusi terhadap peningkatan prestasi peserta didik.

Hasil penelitian menunjukkan bahwa nilai koefisien jalur X terhadap $\mathrm{Y}_{1}$ sebesar $\mathrm{p}_{\mathrm{xy} 1}=$ Beta $=0,784$. Nilai t sebesar 22,168 dengan probabilitas signifikansi $=0,000$. Nilai signifikansi 0,000 $<0,05$, sehingga $\mathrm{H}_{0}$ ditolak. Sehingga, dapat disimpulkan bahwa ada pengaruh yang signifikan kualitas layanan (service quality) akademik terhadap kepuasan peserta didik pada SMPN seKecamatan Ponggok Kabupaten Blitar. Sedangkan untuk nilai kontribusi kualitas layanan (service quality) akademik terhadap kepuasan peserta didik sebesar 0,614 x 100\% =61,4\%.. hal ini sesuai dengan pendapat tingkat kepuasan peserta didik dalam kategori tinggi. Hal ini sesuai dengan pendapat Mustain ( 2017), kualitas pelayanan yang baik adalah pelayanan yang menjamin kepuasan bagi pengguna jasa pendidikan. Kesesuaian harapan peserta didik terhadap layanan yang diberikan oleh sekolah berdampak pada kepuasan peserta didik, namun jika harapan yang dimiliki tidak terpenuhi secara maksimal maka tidak menciptakan rasa kepuasan.

Hasil penelitian menunjukkan bahwa, diperoleh nilai koefisien jalur $\mathrm{X}$ terhadap $\mathrm{Y}_{2}$ sebesar $\mathrm{p}_{\mathrm{xy} 2}=\mathrm{Beta}=-0,134$. Nilai t sebesar $-2,422$ dengan probabilitas signifikansi $=0,016$. Nilai signifikansi $0,016<0,05$, sehingga $H_{0}$ ditolak. Sehingga, ditarik kesimpulan bahwa ada pengaruh yang signifikan kualitas layanan (service quality) akademik terhadap prestasi peserta didik pada SMPN se-Kecamatan Ponggok Kabupaten Blitar. Sedangkan untuk nilai kontribusi kualitas layanan (service quality) akademik terhadap prestasi peserta didik sebesar 0,018 x $100 \%=1,8 \%$, dan sisanya sebesar $98,2 \%$ merupakan kontribusi dari faktor di luar variabel penelitian yang tidak dapat dijelaskan dalam penelitian ini.

Mutu pendidikan menurut Susanto (2016) yaitu mengacu pada hasil pendidikan yang dicapai oleh sekolah dalam bentuk prestasi peserta didik. Prestasi yang dicapai oleh peserta didik atau student achievement dapat dilihat dari hasil tes kemampuan akademik. Produk dalam lembaga pendidikan berupa jasa atau layanan akademik yang memberikan manfaat untuk mengembangkan kemampuan, bakat dan minat yang dimiliki. Sehingga hal tersebut akan menghasilkan output (hasil) yang memiliki kompetensi dan prestasi (Alma dan Hurriyati, 2008). Produk atau jasa lembaga pendidikan yang diberikan kepada peserta didik secara maksimal dan komprehensif dapat memberikan manfaat untuk meningkatkan dan mengembangkan kompetensi serta bakat dan minat peserta didik. Output pendidikan yang berkualitas dapat dilihat dari kompetensi dan prestasinya.

Hasil penelitian nilai koefisien jalur $Y_{1}$ terhadap $Y_{2}$ sebesar $p_{y_{1 y 2}}=$ Beta $=-0,118$. Nilai $t$ sebesar $-2,121$ dengan probabilitas signifikansi $=0,035$. Nilai signifikansi $0,035<0,05$, sehingga $\mathrm{H}_{0}$ ditolak. Sehingga, ditarik kesimpulan bahwa ada pengaruh yang signifikan 
kepuasan peserta didik terhadap prestasi peserta didik pada SMPN se-Kecamatan Ponggok Kabupaten Blitar. Sedangkan untuk nilai kontribusi kepuasan peserta didik terhadap prestasi peserta didik sebesar $0,014 \times 100 \%=1,4 \%$. Hal ini sesuai dengan pendapat Cash, dkk yang termuat dalam Prastiawan, dkk (2016: 215) menyatakan, "A good school facility supports the educational enterprise". Hal ini dapat diartikan bahwa, sekolah yang baik adalah sekolah yang menyediakan fasilitas untuk mendukung pelayanan pendidikan.

Pengaruh kualitas layanan(service quality) akademik $(\mathrm{X})$ terhadap prestasi $\left(\mathrm{Y}_{2}\right)$ yang dimediasi atau melalui variabel kepuasan peserta didik $\left(\mathrm{Y}_{1}\right)$ dengan mengalikan masingmasing nilai beta. Nilai pengaruh hal tersebut sebesar $p_{x y 1} \cdot p_{y 1 y 2}=(0,784) \cdot(-0,118)=-0,092$. Sedangkan nilai kontribusinya dapat dilakukan dengan perhitungan $(-0,092)^{2} \times 100 \%=0,8 \%$. Mutu pendidikan menurut Susanto (2016) yaitu, mengacu pada hasil pendidikan yang dicapai oleh sekolah dalam bentuk prestasi peserta didik. Prestasi yang dicapai oleh peserta didik student achievement dapat dilihat dari hasil tes kemampuan akademik. Penelitian ini penting dilakukan untuk mengetahui tingkat kualitas pelayanan akademik yang diberikan oleh lembaga pendidikan, maka dapat diketahui kontribusi dan pengaruhnya terhadap kepuasan dan prestasi peserta didik.

\section{Simpulan}

Berdasarkan uraian hasil penelitian, dapat dikemukakan beberapa kesimpulan sebagai berikut: (1) berdasarkan hasil olah data deskriptif, maka, kesimpulannya bahwa tingkat kualitas layanan akademik di SMPN se Kecamatan Ponggok berada pada kategori tinggi. Sedangkan jika ditinjau dari masing-masing sub variabel adalah sebagai berikut: (a) dimensi reliability, responden cenderung menyatakan sub variabel reliability dalam kategori sedang; (b) dimensi responsiveness, responden cenderung menyatakan bahwa responsiveness tergolong dalam kategori tinggi; (c) dimensi assurances, responden cenderung menyatakan bahwa assurances tergolong dalam kategori tinggi; (d) dimensi empathy, responden cenderung menyatakan bahwa empathy tergolong dalam kategori sedang; dan (e) dimensi tangible responden cenderung menyatakan tangible tergolong dalam kategori sedang, (2) tingkat prestasi peserta didik di SMPN se Kecamatan Ponggok berada pada kategori sedang, dan (3) ada pengaruh yang signifikan kualitas layanan (service quality) akademik terhadap prestasi peserta didik pada SMPN se-Kecamatan Ponggok Kabupaten Blitar.

\section{Daftar Rujukan}

Alma, B \& Hurriyati, R. (2008). Manajemen Corporate \& Strategi Pemasaran Jasa Pendidikan: Fokus Pada Mutu dan Layanan Prima. Bandung: Alfabeta.

Anggara, P. D. (2015). Studi Eksplorasi tentang Prestasi Akademik dan Non Akademik Peserta Didik di SMP Negeri 2 Jatiroto Kabupaten Wonogiri.

Anita, E. (2016). Pengaruh Penyesuaian Diri, Self Efficacy, dan Kecerdasan Interpersonal Sebagai Variabel Intervening terhadap Prestasi Akademik Mahasiswa Baru Pendidikan Akutansi Universitas Negeri Malang. Skripsi tidak diterbitkan. Malang: Universitas Negeri Malang.

Darmawan, D. (2014). Metode Penelitian Kuantitatif. Bandung:Remaja Rosdakarya Offset.

Dimyati \& Mudjiono. (2009). Belajar dan Pembelajaran. Jakarta: Rineka Cipta.

Mustain, K. (2017). Staff Schedule Analysis of Pharmacy Services Using Simulation Case Study: Medika Antapani Regular. Bandung: Institut Teknologi Bandung.

Prastiawan, A., Mustiningsih, \& Wiyono. B. B. (2016). Hubungan Mutu Fasilitas Sekolah dengan Kepuasan Peserta Didik di SekolahMenengah Atas (SMA) Negeri. Jurnal Manajemen Pendidikan, 25(2), 215-223.

Riduwan \& Kuncoro, E. A. (2007). Cara menggunakan dan Memakai Analisis Jalur (Path Analysis). Bandung:Alfabeta. 
Jurnal Pembelajaran, Bimbingan, dan Pengelolaan Pendidikan, 1(10), 2021, 825-837

Sarwono, J. (2006). Metode Penelitian Kuantitatif dan Kualitatif. Yogyakarta: Graha Ilmu.

Setyadin, B. (2005). Desain dan Metode Penelitian Kuantitatif. Modul tidak diterbitkan. Malang: Instansi Penelitian Universitas Negeri Malang.

Sumarsono, R. B. (2012). Faktor yang Mempengaruhi Kepuasan Mahasiswa terhadap Kualitas Layanan Laboratorium. Jurnal Manajemen Pendidikan, 23(5), 411-417.

Susanto, P. (2016). Produktivitas Sekolah: Teori untuk Praktik di Tingkat Satuan Pendidikan. Bandung: Alfabeta.

Tjiptono, F \& Chandra, G. (2012). Pemasaran Strategik: Mengupas PemasaranStrategik, Branding Strategy, Customer Satisfaction, Strategi Kompetitif, hingga e- Marketing. Yogyakarta: Andi.

Tjiptono, F. (1997). Strategi Pemasaran. Yogyakarta: Andi.

Tjiptono, F. (2007). Pemasaran Jasa. Malang: Banyumedia Publishing.

Tjiptono, F. (2014). Pemasaran Jasa: Prinsip, Penerapan, Penelitian. Yogyakarta:Andi.

Undang-Undang Nomor 20 Tahun 2003 tentang Sistem Pendidikan Nasional. 2013. Bandung: Citra Umbara. 